\title{
Difficulties in histological diagnosis of a case of lymphoma secondary to acute renal failure in a nephrology department in sub-Saharan Africa
}

\author{
Guei Monlet $\operatorname{Cyr}^{1^{*}}{ }^{\circledR}$, Yao Kouamé Hubert ${ }^{\circledR}, \mathrm{N}^{\prime}$ DahKouamé Justin ${ }^{3}$, Lagou Delphine Amelie ${ }^{\circledR}$, Tia \\ Weu Melanie $^{1 \mathbb{1}}$, Konan Serge Didier ${ }^{2}{ }^{\mathbb{D}}$, Choho Carole ${ }^{1}$, Diopoh Sery Patrick ${ }^{2}$, Ackoundou-N'Guessan \\ Kan Clément $^{1}{ }^{\mathbb{D}}$, Gnionsahé Dazé Appolinaire ${ }^{1}$ ()
}

${ }^{1}$ Nephrology Department, University Teaching Hospital of Yopougon, Abidjan, Côte d'Ivoire

${ }^{2}$ Nephrology Department, University Teaching Hospital of Yopougon, Abidjan, Côte d'Ivoire

${ }^{3}$ Department of Anatomy and Pathological Cytology, University Teaching Hospital of Cocody, Abidjan, Côte d'Ivoire

\section{ART I C LE I N F O}

\section{Article Type:}

Case Report

\section{Article History:}

Received: 20 December 2018

Accepted: 14 April 2019

Published online: 16 May 2019

\section{Keywords:}

Renal histology, Lymphoma, Renal failure, Non-Hodgkin's malignant lymphoma, Acute renal failure

\begin{abstract}
A B S T R A C T
Nephrology is a new discipline in sub-Saharan Africa. For a better management of various nephropathies, histological data are necessary in terms of diagnosis, therapy as well as prognosis. However, performing renal needle biopsy is very challenging. We are reporting inadequacy of human, material and financial resources for histological data collection through a case of 21-yearold patient with lymphoma complicated by acute renal failure (ARF).
\end{abstract}

Implication for health policy/practice/research/medical education:

In this paper we are reporting inadequacy of human, material and financial resources for histological data collection through a case of 21-year-old patient with lymphoma complicated by acute renal failure.

Please cite this paper as: Cyr GM, Hubert YK, Justin NK, Amelie LD, Melanie TW, Didier KS, et al. Difficulties in histological diagnosis of a case of lymphoma secondary to acute renal failure in a nephrology department in sub-Saharan Africa. J

Nephropharmacol. 2020;9(1):e12. DOI: 10.15171/npj.2020.12.

\section{Introduction}

Nephrology is a relatively new discipline in Africa, particularly in black African countries. The diagnosis of some renal diseases, such as the renal complications of non-Hodgkin's malignant lymphoma (NHML), is histological. The authors are reporting difficulties in obtaining histological data in a case of lymphoma secondary to acute renal failure (ARF).

\section{Case Presentation}

This is a 21-year-old male patient hospitalized for the treatment of ARF. His history goes back to approximately 4 weeks, prior to his admission for a bilateral lower back pain not suggestive of renal colic and was associated with asthenia. Patient referred to a clinic, where the physical examination results were virtually normal indicating stable hemodynamic condition without fever. The CBC revealed anemia of $10.5 \mathrm{~g} / \mathrm{dL}$, while, other parameters of the CBC were normal. Serum creatinine was $20 \mathrm{mg} / \mathrm{l}$ (177 $\mu \mathrm{mol} / \mathrm{L})$. The thick blood smear was negative. However, the patient received anti-malarial treatment with injectable artemether (a drug to treat malaria) for three days on an outpatient basis without success. The clinical presentation worsened with the appearance of a discrete bilateral parotid swelling and lower limb edema. During a $2^{\text {nd }}$ consultation, he benefited from a symptomatic treatment with oral furosemide. His subsequent progress was marked by the occurrence of an altered general health. He attended another health facility where the laboratory tests revealed a C-reactive protein (CRP) of $22 \mathrm{mg} / \mathrm{L}$ and 
a serum creatinine of $80 \mathrm{mg} / \mathrm{L}(708 \mu \mathrm{mol} / \mathrm{L})$. The patient was then referred to the nephrology department for the management of his renal failure.

The interview did not reveal any particular past medical history or nephrotoxic drug intake. The physical examination identified bilateral edema of the lower extremities, fine crackling in the left lung field, and painless febrile cervical, submandibular and inguinal poly-lymphadenopathy. There was also a bilateral lower back pain without lumbar contact. There was neither hepatomegaly nor splenomegaly.

Biologically, renal function was impaired with urea of $1.98 \mathrm{~g} / \mathrm{L}(33.66 \mathrm{mmol} / \mathrm{L}))$ and serum creatinine of $88 \mathrm{mg} / \mathrm{L}$ $(779 \mu \mathrm{mol} / \mathrm{L})$. The blood electrolytes and transaminases were normal. There was anemia of inflammation with hemoglobin of $9.5 \mathrm{~g} / \mathrm{dL}$. The other parameters of the $\mathrm{CBC}$ were normal. The CRP was $24 \mathrm{mg} / \mathrm{L}$. The $\mathrm{LDH}$ were elevated to $1284 \mathrm{IU} / \mathrm{L}$. Serology for HIV, hepatitis B and $\mathrm{C}$, and syphilis tests were negative. The urine strip test showed presence of protein without leucocytes, red blood cells or nitrites. The 24 -hour proteinuria was $0.24 \mathrm{~g}$.

The chest X-ray showed left perihilar alveolar opacities. There was no mediastinal adenopathy.

On ultrasound, the kidneys had a normal size with multiple hypoechoic nodules formations with no dilatation of the pyelocalyceal cavities. The liver had a normal size, and was heterogeneous with multiple disseminated hypoechoic nodules formations. There was neither ascites nor deep lymphadenopathy.

NHML was strongly suspected during the fine-needle non-aspiration cytology of the cervical lymph nodes. The inguinal lymph node biopsy detected a small-cell NHML (Figure 1).

The kidney and liver biopsies could not perform due to lack of biopsy needles during the patient's hospitalization period.

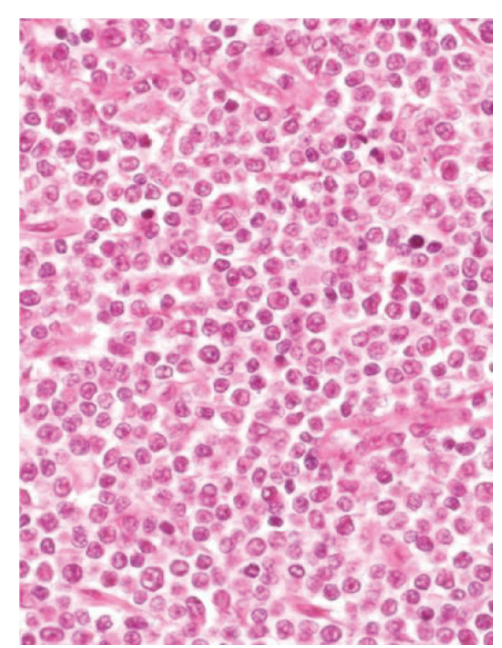

Figure 1. Non-Hodgkin's lymphoma $(\mathrm{HE} \times 25)$; diffuse cell proliferation consisting of lymphocytes, centrocytes and lymphoblasts with cytological nuclear and mitotic atypia.
The diagnosis of diffuse small-cell NHML (with kidney and liver involvement) associated with pneumonitis was made. There was a favorable outcome of pneumonia with antibiotic therapy. Given the renal failure severity, he underwent a total of six hemodialysis sessions.

Immunohistochemistry could not perform while the patient died before starting the chemotherapy, after one week of hospitalization.

\section{Discussion}

The clinical manifestations of renal lymphomas are predominated by the classic triad of: lumbar mass, lower back pain and hematuria. This triad was associated with an altered general health or fever. Our patient presented only with altered general health and lower back pain. There was no hematuria.

Renal involvement is either secondary to hematogenous diffusion in the context of multi-organ involvement or due to contiguous retroperitoneal lymphadenopathy. In rare cases, renal involvement may be primitive as reported by some authors $(1,2)$. The diagnostic criteria for primary renal lymphoma consist of (3);

- Initial presentation in the form of unexplained ARF

- Increase in the kidneys size

- The diagnosis is confirmed by the histological assessment of the kidneys

- Absence of extra-renal lymphomatous involvement

- Regression of symptomatology after treatment

In our patient case, we suspected kidney involvement secondary to hematogenous diffusion in this context of multi-organ involvement (kidney involvement with multiple hypoechoic nodules formations, ARF and liver involvement with multiple hypoechoic nodules formations). Kidney involvement by contiguity was ruled out in our case in the absence of retro-peritoneal adenopathy. Moreover, this case did not meet the diagnostic criteria for primary renal lymphoma, since the kidneys did not increase in size and he presented with extra-renal lymphomatous involvement (cervical and inguinal lymphadenopathies).

The involvement may also be secondary to an immunological mechanism. The diagnosis of renal lymphoma is histological. In our patient case, the kidney biopsy could not perform owing to stock-out of biopsy needles. However, in view of the fine-needle nonaspiration cytology of the cervical lymph nodes strongly suspected of non-Hodgkin's malignant lymphoma. The histological diagnosis of lymphoma made for the inguinal lymph node biopsy. The final diagnosis of NHML with probably extra-ganglionic localizations was conducted based on the ultrasound images of the liver and kidneys, which was complicated by ARF.

Indeed, the pharmacy of the University Teaching Hospital of Yopougon (a city of Abidjan) does not have renal biopsy needle, or single-use renal biopsy gun yet. 
We have been performing percutaneous renal biopsy since 2010 using a biopsy gun to which we fix the needles. This gun is graciously made available to the nephrology department by a physician of that department. The city pharmacies also have neither needles nor kidney biopsy guns. This is probably due to the low demand, while there are only two public departments of nephrology in Côte d'Ivoire. The supply of needles has been made by a private supplier engaging in informal-sector activities with often stock-out periods.

The minimum cost of performing a renal needle biopsy is 167000 CFA francs (i.e. $€ 254.6$ or US\$310). It includes the purchase of the biopsy needle, asepsis equipment, local anesthesia, analgesics, the costs of 2-day hospitalization in the absence of complications and the costs of the anatomical pathology examination. This cost amounts to $€ 243.22$ (US\$299) in France (4) and US\$1968 (€ 1600) in the United States (5), where health insurance has been provided by private insurance companies. This cost of $€$ 254.6 is high for our population, while, the majority of whom are poor without health insurance coverage.

Besides the lack of material and financial resources, there is a shortage of pathologists (see Table 1). In Côte d'Ivoire, there is only one pathologist who specialized in renal pathology for a population of 24.4 million inhabitants (6). The majority of French-speaking African countries do not have pathologists who specialized in renal pathology. In 2017, France had 1618 pathologists of all specialties (7).

In terms of treatment, there are several modalities; chemotherapy, surgery or radiotherapy (8). With regard to chemotherapy, it is actually multi-agent chemotherapy, mostly the CHOP type (cyclophosphamide, doxorubicin, vincristine, and prednisone), which is increasingly associated with rituximab. It gives better results as compared to conventional chemotherapy (9).

\section{Conclusion}

Histology is essential for diagnosis, therapy and prognosis of several kidney diseases. However, when performing renal needle biopsy, we encounter several barriers in our developing countries, particularly in Africa. These barriers can be summed up in the lack of human, material and financial resources.

\section{Authors' contribution}

Authors wrote the manuscript equally.

\section{Conflicts of interest}

The authors report no conflicts of interest.

\section{Ethical considerations}

Ethical issues (including plagiarism, data fabrication, double publication) have been completely observed by the authors. The patient has given his informed consent regarding publication of this case report.

\section{Funding/Support}

None.

\section{References}

1. Belbaraka R, Elyoubi MB, Boutayeb S, Errihani H. Primary renal non-Hodgkin lymphoma: an unusual diagnosis for a renal mass. Indian J Cancer. 2011;48:255-6.doi: 10.4103/0019-509X.82880.

2. Geetha N, Shahid A, Rajan V, Jacob PM. Primary renal lymphoma-a case report. Ecancermedicalscience. 2014; 8:466. doi: 10.3332/ecancer.2014.466.

3. Charasse C, Colcanap O, Bousser J, Catroux B . Lymphome rénal primitif révélé par une insuffisance rénale oligoanurique: une observation. Rev Med Interne, 1994; 15 (Suppl 1) S138

4. Bourgoin H, P. Gatault, P. Mutinelli, J. Grassin, J. Halimi, M. Buchler. La ponction biopsie rénale: étude pharmacoéconomique. Le Pharmacien Hospitalier et Clinicien 2012; 47: S83.

5. Chesney DS, Brouhard BH, Cunningham RJ.Safety and cost effectiveness of pediatric percutaneous renal biopsy. Pediatr Nephrol. 1996;10:493-5.

6. Société Ivoirienne de Pathologie. XIV èmes Journées

Table 1. Distribution of pathologists in the French-speaking Africa division of the international academy of pathology (6)

\begin{tabular}{lccc}
\hline Countries & Number of pathologists & Pathologists who specialized in renal pathology & Population in mid-2017 (in million) \\
\hline Cote d'Ivoire & 11 & 1 & 24.4 \\
Senegal & 10 & 1 & 15.8 \\
Burkina Faso & 7 & 0 & 19.6 \\
Benin & 6 & 0 & 11.2 \\
Central African Republic & 6 & 1 & 4.7 \\
Mali & 4 & 0 & 18.9 \\
Guinea (Conakry) & 4 & 0 & 11.5 \\
Mauritania & 3 & 0 & 4.4 \\
Niger & 3 & 0 & 20.6 \\
Togo & 3 & 0 & 7.8 \\
Chad & 2 & 14.9 & \\
\hline
\end{tabular}


de la Division d'Afrique Francophone de l'Académie Internationale de Pathologie (DAF-AIP) et la II èmes Journées de la Société Ivoirienne de Pathologie (SIPath) du 28 Février au 2 Mars 2018. https:/www.sipath-ci.org. (consulté le 20/03/2018)

7. Direction de la recherche, des études, de l'évaluation et des statistiques. France : Données sur les médecins au $1^{\text {er }}$ janvier issues de lexploitation statistique du RPPS. Sources et définitions. http://www.data.drees. sante.gouv.fr/ReportFolders/reportFolders.aspx?IF_ ActivePath=P,490,497,514 (consulté le 18/03/2018).

8. Olusanya AA, Huff G, Adeleye O, Faulkner M, Burnette
$\mathrm{R}$, Thompson $\mathrm{H}$, et al. Primary renal non-Hodgkin's lymphoma presenting with acute renal failure. J Natl Med Assoc. 2003;95:220-4.

9. Diskin CJ, Stokes TJ, Dansby LM, Radcliff L, Carter TB, Graves E. Acute renal failure due to a primary renal B-cell lymphoma. Am J Kidney Dis. 2007;50:885-9. doi:10.1053/j. ajkd.2007.08.008.

10. Gilles Pison. Tous les pays du monde. Population \& Sociétés, $\mathrm{N}^{0}$ 547, Paris, 2017. https://www.ined.fr/fichier/s_ rubrique/26889/547.population.societes.septembre.2017. tous.les.pays.du.monde.fr.pdf. (consulté le 12/03/2018).

Copyright $\odot 2020$ The Author(s); Published by Published by Society of Diabetic Nephropathy Prevention. This is an open-access article distributed under the terms of the Creative Commons Attribution License (http://creativecommons.org/licenses/by/4.0), which permits unrestricted use, distribution, and reproduction in any medium, provided the original work is properly cited. 